\title{
Hennegoides longitudinalis n. gen. n. sp., a myxosporean parasite of Osphronemus gourami from Thailand
}

\author{
Jiří Lom ${ }^{1}$, Kamonporn Tonguthai ${ }^{2}$, Iva Dyková ${ }^{1}$ \\ ${ }^{1}$ Institute of Parasitology, Czech Academy of Sciences, Branisovska 31, 37005 Ceske Budéjovice, Czechoslovakia \\ ${ }^{2}$ National Inland Fisheries Institute, Kasetsart University Campus, Bangkhen, Bangkok 10 900, Thailand
}

ABSTRACT: A new myxosporean parasite, Hennegoides longitudinalis n.gen. n.sp., is described from the intestinal submuccsa of gouramy Osphronemus gourami from Thailand. The genus is characterized by asymmetrical spores with caudal extensions, by polar capsules with polar filament arranged in elliptical turns lying in the longitudinal axis of the capsule, and by the absence of pansporoblasts in sporogenesis. Its pathogenic potential is yet to be assessed.

While checking the health condition of gouramy Osphronemus gourami, an economically important Southeast Asian fish species, established in cultures in the reservoir at Kanchnaburi Province about $250 \mathrm{~km}$ from Bangkok (Thailand), we came across a myxosporean infecting the intestine. Adult specimens were collected during March 1988. The overall prevalence of the infection was $100 \%$ (22 specimens infected out of 22 examined). The infection was generally moderate. Infected gouramy were also found in rivers north of Bangkok. Fresh spores released from mature trophozoites were measured and photographed. Samples of infected tissue were fixed in $10 \%$ neutral formalin. Some of them were postfixed in $1 \% \mathrm{OsO}_{4}$ in $0.1 \mathrm{M}$ cacodylate buffer, embedded in Epon-Araldite and ultrathin sections examined in a Phillips 420 B electron microscope.

The trophozoites in the form of plasmodia about 0.25 to $0.3 \mathrm{~mm}$ in size were localized in the subepithelial layer of the middle part of the intestine (see Fig. 2). In a grown state, the plasmodium had a rather thin cortical layer beneath which were the developmental stages and, eventually, only mature spores.

The mature spores are quite asymmetric in frontal view (Fig. 1). One side is slightly, the other strongly vaulted and the caudal appendages extend to one side, not axially. Thus the outline is slightly reminiscent of the profile of a mouse with a short tail. In fresh state, the size of the spore body is $11.5(10.9$ to 12.2$) \times 5.4(4.7$ to 6.3) $\mu \mathrm{m}(\mathrm{n}=20)$. Caudal appendages, $5.3(3.4$ to 6.8$)$ $\mu \mathrm{m}$ long, extend obliquely from the posterior end and are only slightly divergent posteriorly. The ellipsoidal polar capsules of equal size, $5.2(4.3$ to 5.7$) \times 2.1(1.7$ to 2.2) $\mu \mathrm{m}$ are set obliquely in the anterior part of the spore. In fresh spores (Fig. 3) the polar filament is difficult to discern within the capsule; in Nomarski interference phase contrast it can be seen to be coiled in longitudinal threads parallel to the longitudinal axis of the capsule (Fig. 4).

The electron microscope reveals 4 threads of a filament which is - using the terminology applied in microsporidia - anisofilar, i.e. tapers gradually to its end (Fig. 5). The longitudinal orientation of the threads is also seen in longitudinal sections (Fig. 6). The structure of the polar capsules complies in other respects with the pattern found in most myxosporean species

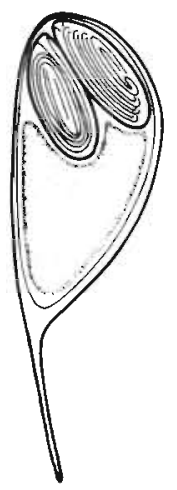

Fig. 1. Line drawing of Hennegoides longitudinalis 

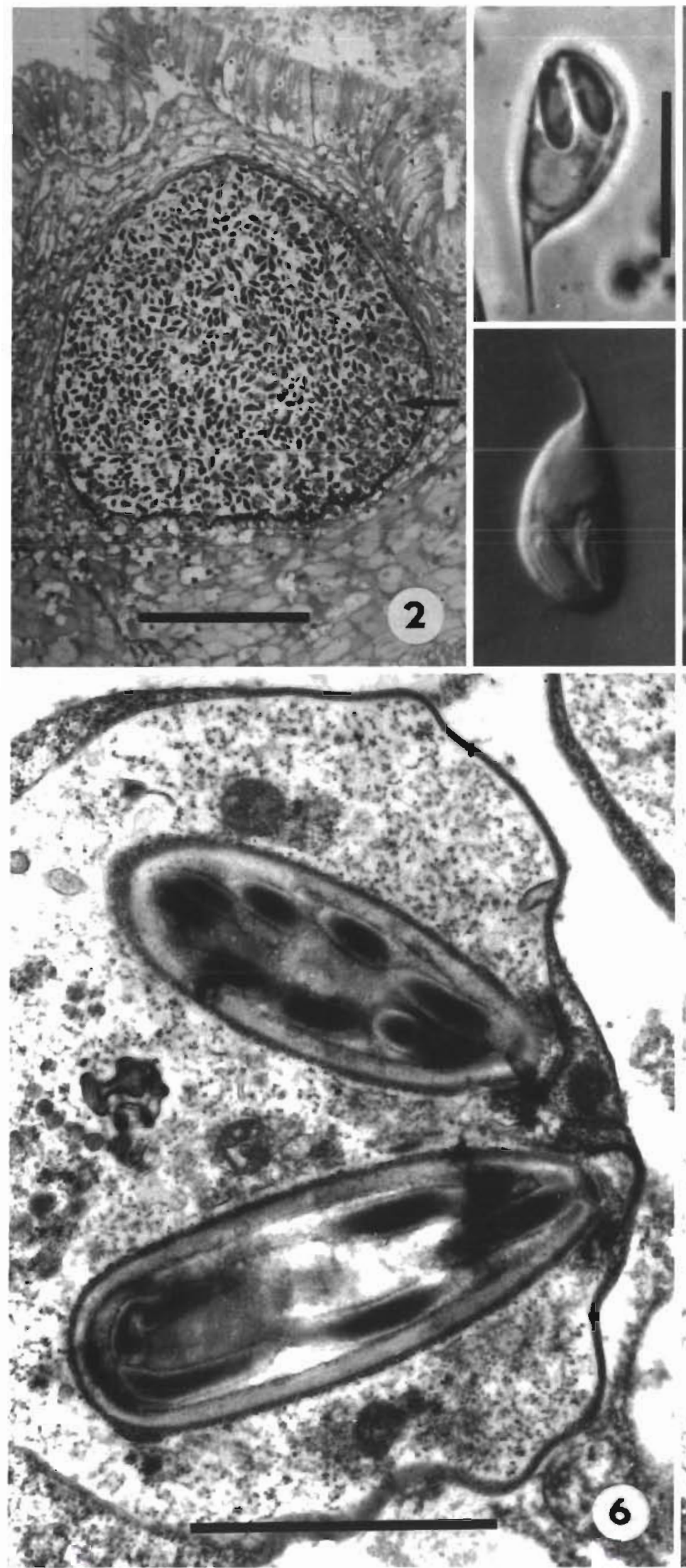
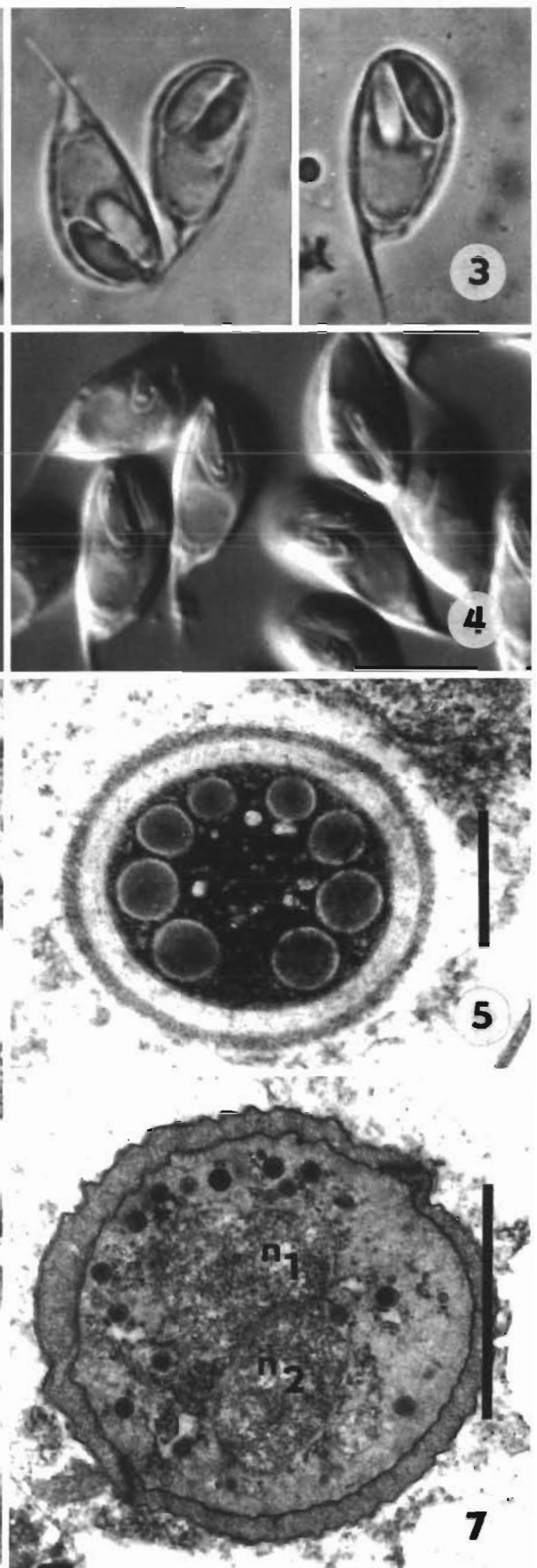
Figs. 2 to 7. Henneguya longitudinalis parasitising Osphronemus gourami. Fig. 2. A trophozoite in the subepithelial layer of the intestine, containing mature spores except for the right side (arrow) where developmental stages can still be seen. Bar $=100 \mu \mathrm{m}$. Figs. $3 \& 4$. Mature spores as seen in transmitted light and Nomarski interference phase contrast, respectively. Bar $=10 \mu \mathrm{m}$. Fig. 5 . Transverse section through an almost mature polar capsule showing the decreasing polar filament diameter. Bar $=0.5 \mu \mathrm{m} . \overline{\text { Fig. }}$. An almost longitudinal section through almost mature polar capsules within a sporoblast. Bar $=2 \mu \mathrm{m}$. Fig. 7 . Section through the sporoplasm showing spherical sporoplasmosomes and the 2 nuclei $\left(\mathrm{n}_{1}, \mathrm{n}_{2}\right)$ adhering closely together. Bar $=2 \mu \mathrm{m}$

examined thus far. At the apex of the capsule there is no distinct cap. The sporoplasm contains numerous sporoplasmosomes and 2 closely apposed nuclei reminiscent of a microsporidian diplocaryon (Fig. 7). There are no pansporoblasts; the spores are produced singly.

Taxonomic position. The present species has spores similar to those of the genus Henneguya, yet it is different from all its 114 hitherto recorded species in several important respects.

The spore is asymmetric with polar capsules set obliquely, not symmetrically to the longitudinal axis of the spore. Only Henneguya thermalis described by Seenappa et al. (1981) is similar; the original drawing of the spore, however, is too poor to permit accurate comparison.

The polar filament is arranged in threads situated parallelly to the longitudinal axis of the capsule and gradually tapers to the end. In most Henneguya species, however, the filament turns are perpendicular to, in some at an oblique angle to the capsule length and the filament has the same diameter throughout its length. In Henneguya (e.g. Schubert 1968, Current \& Janovy 1977, Current 1979), as well as in most other myxosporeans (e.g. Lom \& de Puytorac 1965, Desportes \& Théodoridés 1982, Desser \& Molnár 1982), the transverse section of the nascent filament has the shape of a figure 8 , reflecting its longitudinally twisted form, while in the present species it is quite circular.

Another important difference from Henneguya is the absence of pansporoblasts in spore formation; in most genera, sporoblast formation follows the same pattern [exceptions being the genera Kudoa (Lom \& Dyková 1988) and Chloromyxum (Lom \& Dyková unpubl.)]. Careful comparison revealed that this organism is different from all other myxosporean genera described until now.

Summing up all the differences, we can consider the present species a new one and establish it as Hennegoides longitudinalis $\mathrm{n}$. gen., n. sp. The generic name reflects the similarity to the genus Henneguya. We assign Hennegoides to the family Myxobolidae Thélohan, 1892, suborder Platysporina Kudo, 1918, order Bivalvulida Shulman, 1959 with the following diagnosis:

Asymmetric spores with non-axially attached caudal appendages. Polar capsules with longitudinally arranged turns of an anisofilar polar filament located obliquely in the spore apex. Pansporoblast formation absent.

\section{LITERATURE CITED}

Desportes, I., Théodoridés J. (1982). Données ultrastructurales sur la sporogénese de deux myxosporidies rapportées aux genres Leptotheca et Ceratomyxa parasites de Merluccius merluccius (L.) (Téléostéen Merluciidae). Protistologica 18: 533-557

Desser, S. S., Molnár, K. (1982). Ultrastructural observations on sporogenesis of Thelohanellus nikolskii (Myxozoa: Myxosporea). Molecul. Biochem. Parasitol. Suppl. 698

Current, W. L. (1979). Henneguya adiposa Minchew (Myxosporida) in the channel catfish: ultrastructure of the plasmodium wall and sporogenesis. J. Protozool. 26: 209-217

Current, W. L., Janovy, J. (1977). Sporogenesis in Henneguya exilis infecting the channel catfish: an ultrastructural study. Protistologica 13: 157-167

Lom, J., Dyková, I. (1988). Sporogenesis and spore structure in Kudoa lunata (Myxosporea, Multivalvulida). Parasitol. Res. 74: $521-530$

Lom, J., de Puytorac, P. (1965). Studies on the myxosporidian ultrastructure and polar capsule development. Protistologica 1: 53-65

Seenappa, D., Manohar, L., Prabhu, R. M. (1981). Henneguya thermalis $\mathrm{n}$. sp. parasitic in the brain tissue of the loach, Lepidocephalichthys thermalis (Hamilton). Current Sci. 50: $295-296$

Schubert, G. (1968). Elektronenmikroskopische Untersuchungen zur Sporenentwicklung von Henneguya pinnae Schubert (Sporozoa, Myxosporidea, Myxobolidae), Z. Parasitenkd. 30: 57-77

Manuscript first received: April 10, 1991

Accepted: May 17, 1991 